\title{
THE RELATIONSHIP BETWEEN SCEPTICISM TOWARDS ADVERTISING AND THE FIVE-FACTOR PERSONALITY TRAITS
}

\author{
Ceyda DENEÇLI*
}

\begin{abstract}
Individuals are increasingly becoming more aware and approaching the advertising claims presented to them with scepticism; for this reason, the concept of scepticism towards advertising is important. Individuals who approach advertising with scepticism sometimes do not believe in the claims put forward in the advertisements and sometimes do not trust the justifications related to the products or brands presented to them. The scepticism felt towards advertisements has been observed to decrease the effect of the persuasive powers of the advertisements on the individuals. The personality traits, demographic characteristics, age, education, etc. of individuals have been observed to produce different sceptical attitudes. In view of this, it is the aim of this study to identify the relationship between personality traits within the scope of the five-factor personality theory and the scepticism of consumers towards advertisements. The study has been applied to 132 people who have been selected through convenience sampling. In order to identify the personality traits related to the levels of sceptic approaches towards advertisements, correlation analysis has been used and in order to identify personality traits that have an effect on the levels of sceptic approaches towards advertisements, multiple regression analysis has been used. The results of the study have shown that the dimensions of Sense of Responsibility (Standard Beta=$0,20 p=0,02<0,05$ ), Extroversion (Standard Beta=0,17p=0,04<0,05) and Openness to Experience (Standard Beta=0,18p=0,04<0,05) have a significant impact on the level of scepticism in consumers' approach towards advertisements.
\end{abstract}

Keywords: Scepticism, scepticism towards advertisements, personality, personality traits

JEL Classification: M37

* Assist. Prof. Dr. Ceyda Deneçli, Nişantaşı University, Faculty of Art and Design, Department of Radio, Television and Cinema, ceyda.denecli@gmail.com 


\section{REKLAMA KARŞI ŞÜPHECİİĞİN BEŞ FAKTÖR KİŞİİK ÖZELLIKLERIYLE ILIŞKİSİ}

$\ddot{O}_{z e t}$

Zaman içinde bireylerin giderek daha bilinçlenmesi ve kendilerine sunulan reklam iddialarına karşı şüphe ile yaklaşmaları reklama karşı şüphe kavramının önemini göstermektedir. Reklama karşı şüphe ile yaklaşan bireylerin, kimi zaman reklamda öne sürülen iddialara inanmadıkları kimi zaman ise kendilerine sunulan ürün ya da marka ile ilgili gerekçelere güvenmeme sonucunu doğurmaktadır. Reklama karşı duyulan şüphenin, reklamların bireylerin üzerindeki ikna etkisini azalttığ da görülmektedir. Reklama karşı şüphenin tüketicilerin kişilik özellikleri, demografik özellikler, yaş, ĕgitim vb. konulara bağll olarak değişiklik gösterdiği görülebilmektedir. Bu doğrultuda bu araştırmada tüketicilerin reklama karşı şüphe ile yaklaşımlarl ile beş faktör kişilik teorisi kapsamında kişilik özellikleri arasındaki ilişki belirlenmesi amaçlanmıştır. Araştırma kolayda örnekleme yöntemiyle ulaşılmış 132 kişi üzerinde gerçekleştirilmiştir. Reklamlara karşı şüpheyle yaklaşma düzeyleriyle ilişkili kişilik özelliklerini belirlemek amacıyla korelasyon analizi; reklamlara karşı şüpheyle yaklaşma düzeyleri üzerinde etkili olan kişilik özelliklerini belirlemek amacıyla ise çoklu regresyon analizi kullanılmıştır. Araştırma sonuçları beş kişilik özelliği içerisinden Sorumluluk Bilinci (Standart Beta=-0,20 p=0,02<0,05), Dişadönüklük (Standart Beta $=0,17 p=0,04<0,05$ ) ve Deneyime Açıklı (Standart Beta =0,18p=0,04<0,05) boyutlarının tüketicinin reklamlara karşı şüpheyle yaklaşma düzeyi üzerinde anlamlı bir etkiye sahip olduğunu ortaya koymuştur.

Anahtar Kelimeler: Şüphe, reklama karşı şüphe, kişilik, kişilik özellikleri

JEL Sınıflaması: M37

\section{Introduction}

Today, the intense competitive environment has presented corporations with the necessity to promote their products or brands to their consumers and to prove that their products are of high quality. In order to be able to realise this, advertisements, which are one of the methods the companies resort to, are designed with the object of persuading the consumers. Therefore, care is taken to get to know the characteristics of the target group of the advertisement and by taking these into consideration, various appeals are made use of in the messages of the advertisement.

In parallel with the compliance of the companies with the current market, the attitude of consumers towards companies and brands has also changed. In the past, consumers were individuals who easily believed in the messages conveyed to them, both by companies and advertisements, and easily accepted whatever was being presented to them, but over time they have become more conscious and critical. ${ }^{1}$ As a

1 Kaj P.N. Morel - Ad Th.H Pruyn "Consumer Scepticism Toward New Products", E-European Advances in Consumer Research, Ed.: Darach Turley and Stephen Brown, Provo, UT, Association for Consumer Research, 2003, p.351-358. p.351. 
consequence of the increasing awareness of consumers, it can be observed that a suspicious approach to the claims presented to them in advertisements has developed. This suspicious approach of consumers towards advertisements also causes them to adopt a prejudiced attitude and a state of disbelief, whenever they recognise that the advertisements are being produced to persuade them. The personality traits of individuals can cause differences in the reactions they display towards brand or product selections, or activities presented with promotional purposes. For this reason, this study, which aims at determining the relationship between the scepticism felt towards advertisements and individuals' personality traits and identifying which individuals, with which personality traits, approach advertisements with scepticism, will deal with scepticism towards advertisements within the framework of the five-factor personality theory.

\section{The Concept of Scepticism and Scepticism towards Advertisements}

Scepticism, which means suspiciousness, has formed the basis of a philosophical school and was embraced by those researchers who continuously searched for reality in the Hellenistic Roman times. Scepticism, which was the third significant philosophical school of the period, is derived from the Greek word 'skeptikoi'. ${ }^{2}$ Scepticism, or suspiciousness, is defined "in general as an attitude where nothing is accepted as it is, everything is filtered through a certain criticism; the understanding which claims that scepticism is mandatory and inevitable prior to reaching a certain truth". 3 According to sceptics, no one can know whether a fact or a view is right or wrong and there is no reason for them to believe in a particular view. Therefore, a person neither accepts nor denies that a view is right or wrong. Sceptics only observe a view; they do not judge it. ${ }^{4}$ It can be observed that some individuals view the claims presented by commercials or other methods of persuasion with similar scepticism.

Scepticism against advertisements is defined as the attitude of consumers to the claims made by advertisements with the purpose of informing them ${ }^{5}$, disbelief of the claims made in the advertisements and distrust of their justifications. ${ }^{6}$ Advertisements, which are defined as certain efforts of communication aimed at a certain target group within a certain period of time, have functions such as informing, persuading and reminding. Due, in particular, to the increase of competition, it can be seen that some brands stand out among other brands and their efforts to create answers to spe-

2 Ahmet Cevizci, Felsefe Tarihi, İstanbul, Say Yayınları, 2010, p.155

3 Ahmet Cevizci, Felsefe Sözlüğü, İstanbul, Paradigma Yayıncılık, 2005, p.1045

4 Gunnar Skirbekk - Nils Gilje, Antik Yunan'dan Modern Döneme Felsefe Tarihi, Translated by: Emrah Akbaş and Şule Mutlu, İstanbul, Kesit Yayınları. (Original Book Published in 2001). p.139; Ernest Sosa, Stroud Barry, "Philosophical Scepticism and Epistemic Circularity”, Supplementary Volumes, Vol.68, 1994, p. 263-307. p.291-292

5 Carl Obermiller - Eric R. Spangenberg, "Development of a Scale to Measure Consumer Skepticism Toward Advertising", Journal of Consumer Psychology, Vol.7, No.2, 1998, p. $159-186$. p. 160

6 David M. Bousch et al., "Adolescent Skepticism toward TV Advertising and Knowledge of Advertiser Tactics", Journal of Consumer Research, Vol.21, No.1, 1994, p.165-175. p.165 
cific demands increase. ${ }^{7}$ Advertisements attempt to develop or change the attitudes and behaviours of consumers by presenting rational arguments and addressing the emotions of consumers in their messages; they create ideas in the consumers related to a brand or a product and prompt them to take action. ${ }^{8}$ However, in order for advertisements to be effective for consumers, they need to create trust in them. Trust, in turn, is created when the messages of advertisements are perceived by consumers to be sincere and open. Otherwise, if consumers think that the messages of advertisements are bending the truth, they will result in negative reactions. ${ }^{9}$

Scepticism causes a change in the meaning of the messages given in advertisements and consumers are likely to misinterpret their claims. Scepticism prevents consumers from understanding the main theme which the advertisements are attempting to present and makes them believe that the claims of the advertisements are designed to trick them. Therefore, individuals develop negative attitudes towards the products or brands which are advertised..$^{10}$ It has been stated that the scepticism of consumers towards advertisements does not only mean scepticism towards the product being marketed or the information in the messages of the advertisement, but also, since it implies a belief that the information presented is not true, a negative prejudice on the part of the consumers. ${ }^{11}$ In relation to sales, since scepticism against advertisements is a basic attitude which influences the reaction of consumers to advertisements, it can be observed that scepticism reduces the persuasive effect of advertisements on consumers and plays a significant role in the impact of an advertisement. ${ }^{12}$ The more a person is suspicious, the more he critically scrutinises the claims put forward and refuses to accept them at face value. Scrutinising messages in a detailed manner helps people make their buying decisions in a more conscious or intelligent way. ${ }^{13}$ It has been demonstrated that consumers who are highly suspicious of advertisements like them less, trust them less and watch them less. It has also been determined that these people prefer advertisements with emotional appeals, rather than advertisements which contain informational messages. ${ }^{14}$

7 Philip Kotler - Gary Armstrong, Principles of Marketing, New Jersey, Pearson Prentice Hall, 2008, p.426-427

8 Williams Wells et al., Advertising Principles and Practice, New Jersey, Pearson Prentice Hall, 2006, p.113

9 John O'Shaughnessy - Nicholas Jackson O'Shaughnessy, Persuasion in Advertising, London, Routledge, 2003, p.6

10 Robin J.B. Ritchie, "The Mutable Meaning of Ads: Advertising thorough the Eyes of the Skeptical Consumer", Faculty of Commerce. University of British Columbia. Working Paper-Version, 2001

11 Morel- Pruyn, Consumer...ibid.p.351

12 Nüket Elpeze Ergeç, “Ad Tactics And Skepticism”, 4th International Symposium Communication in the Millennium, Eskişehir, 14-16 June 2006, p.154-164. p.155

13 Tamara Mangleburg - Terry Bristol, "Socialization and Adolescents Scepticism toward Advertising”, Journal of Advertising, Vol.27 No.3, 1998, p.11-21. p.12

14 Carl Obermiller et al., "Ad Skepticism: The Consequences of Disbelief”, Journal of Advertising, Vol.34 No.3, 2005, p.7-17. p.319-321 
It can be seen that, day by day, individuals are becoming more suspicious of the things they read or watch in advertisements. Since they are subject to too many promotions, they have begun to distrust the claims related to the products or brands presented in the advertisements. Therefore, consumers mostly prefer to make a decision based on information they attain from their friends, the experts on the subject or sales representatives, instead of the information presented to them in advertisements. ${ }^{15}$ However, since children are small and do not have the knowledge and experience required to understand and evaluate the reasons behind the appeal used by advertisements in order to make their claims convincing, they are more vulnerable to the messages of advertisements. ${ }^{16}$ On the other hand, as a consequence of young people interacting with their families, friends, social media and tools such as television, it is observed that they develop suspicious attitudes towards advertisements. In addition, ready access to information related to the market is influential on the evaluation of advertisements by young people and allows them to recognise more of the persuasive tactics used by advertisers. ${ }^{17}$

In cases where individuals have information related to the persuasive tactics directed towards them, according to the "persuasion knowledge model", which deals with individuals' reactions towards these persuasive efforts, this information causes a change in their reactions to the persuasion tactics used. In this model, it is stated that there are three types of knowledge which can be accessed. These consist of the consumers, voters, etc., who are defined as the 'target' to which the persuasion efforts are directed; the agencies, sales representatives and other mediators who manage the advertising campaigns and who design and structure the persuasion initiative, defined as the 'agent'; and the third type, defined as the persuasion 'attempt', expresses strategic behaviours, which include the tactics used by mediators, along with the messages incorporated in the presentations, designed to influence the attitudes, behaviour and activities of consumers. ${ }^{18}$

While advertisers try to attract attention in order to persuade consumers, tactics such as showing the brand name at the end of the advertisement, or giving place to appeals are used in advertisements. These tactics are used in order to allow those who watch the advertisement to process the messages of the advertisements in their minds. However, an increase in the level of processing of messages in consumers' minds can cause persuasion information to be active and consumers to arrive at inaccurate judgments. ${ }^{19}$ This guidance carried out implicitly in order to persuade consum-

15 Michael Phillips - Salli Rasberry, Marketing Without Advertising, USA, Nolo, 2001, p. 10

16 George E. Belch - Michael A. Belch, Advertising and Promotion: An Integrated Marketing Communications Perspective, America, Mc Graw Hill, 2003, p. 772

17 Mangleburg - Bristol, Socialization...ibid., p.11-21

18 Marian Friestad - Peter Wright, "The Persuasion Knowledge Model: How People Cope with Persuasion Attempts”, Journal of Consumer Research, Vol.21 No.1, 1994, p.1-31. p.2

19 Margaret C. Campbell, "When Attention-Getting Advertising Tactics Elicit Consumer In- 
ers and claims given place to in advertisements, causes consumers to feel scepticism. Consumers, who think that companies or advertising agencies design advertisement messages in order to trick and manipulate them, show resistance to being persuaded. ${ }^{20}$

People acquire information about persuasion tactics throughout their lives in various ways. Individuals interact with friends, family, colleagues, etc. and acquire information as a result of conversations about how people's emotions and behaviours can be affected, or by observing marketers and other advertising agencies and comments about advertising and marketing tactics used in the media. As a result of this knowledge, which shapes people's understanding of persuasion information, the effects of companies or people who gradually try to influence people's attitudes and behaviour change, along with the reactions of individuals to these persuasion techniques. ${ }^{21}$

Since, over time, consumers become more suspicious about the characteristic claims made for brands in advertisements, they begin to wish to experience the brand for themselves and talk over what other consumers feel and think about brands before they make a decision. ${ }^{22}$ Today, the fact that consumers are assuming the status of market administrators has caused the previously used marketing methods to begin losing their effect. Consumers reject information, entertainment or marketing activities directed at them when they are not interested. Individuals call for more interest, demand individualised messages and expect more interactivity. People have turned into selective, suspicious and demanding consumers, rather than passive individuals who accept the given message without question. ${ }^{23}$ It is observed that advertisers and others who carry out marketing activities present various activities aimed at grabbing the attention of consumers by including them in the promotional activities within an interactive environment, in order to prevent their suspicious approach towards products and advertisements.

For instance, the T-mobile brand has invited individuals to 'Street Gigs', which is the best place for the company to test the latest technology. As another example, Innocent Smoothies, which is a drink brand, has organized an activity called "Fruitstock", which allows consumers to communicate with the brand. ${ }^{24}$ In view of these points, it can be stated that the gradually increasing suspicion of consumers is very

ferences of Manipulative Intent: The Importance of Balancing Benefits and Investments", Journal of Consumer Psychology, Vol. 4 No.3, 1995,p.225-254. p.228

20 Campbell, When...ibid., p.227; Amna Kirmani - Rui Juliet Zhu, "Vigilant Against Manipulation: The Effect of Regulatory Focus on the Use of Persuasion Knowledge", Journal of Marketing Research, Vol. 44 No.4, 2007, p.688-701. p. 689

21 Friestad - Wright, The Persuasion...ibid., p.2

22 Elizabeth Parsons - Pauline Maclaran, Contemporary Issues in Marketing and Consumer Behaviour, Oxford, Butterworth - Heinemann, 2009, p. 46

23 Christopher Vollmer - Geoffrey Precourt, Always On: Advertising, Marketing, and Media in an Era of Consumer Control, Amerika, Mc Graw Hill, 2008, p.34-35

Parsons - Maclaran, Contemporary...ibid., p.46 
closely related both to the increase of people's knowledge, experience and scepticism towards advertisements and to the personality traits of individuals.

\section{Five-factor Personality Traits and Scepticism towards Advertisements}

Personality is "a type of relationship the individual forms with his inner and exterior environment, which distinguishes him from others and is consistent and structured". ${ }^{25}$ According to another definition, personality is unique and permanent thought, emotion and behaviour models which symbolise the harmony of each individual to situations in his life. ${ }^{26}$ Personality, which can change (displaying differences according to the individual) in reaction to major events, such as the death of a loved one, separation from a spouse, or achieving progress in a career, but also has the capacity to be consistent and permanent, is defined as the inner psychological characteristics which determine how the individual treats his environment and reflects these. Personality allows consumers to be classified into different groups in accordance with their specific characteristics. ${ }^{27}$

Personality traits are individual difference variables ${ }^{28}$ and are characteristics which distinguish individuals in a permanent and consistent manner from others. ${ }^{29}$ In relation to defining personality and its measurement, there are numerous different studies and views in literature. However, due to the differing views of the researchers, a great number of scales and personality evaluations and have emerged, while scales of the same name measuring completely different concepts, or scales with different names measuring very similar concepts have caused an even greater problem. Therefore, the researchers needed a certain typology in terms of personality. The development of such a typology would allow researchers to determine certain factors related to personality traits and analyse these traits within these factors, instead of analysing a great number of separate traits related to personality. ${ }^{30}$ As a result of long studies, an agreement has been reached on a typology which embodies five factors relating to personality traits under the name "Big Five" (big five trait taxonomy). ${ }^{31}$ In the naming

25 Yavuz Odabaşı - Gülfidan Barış, Tüketici Davranışı, İstanbul, Kapital Medya Hizmetleri A.Ş, 2007, p.190

26 Eric Arnould et al., Consumers, America, Mc Graw Hill, 2004, p.389

27 Leoon Schiffman - Leslie Lazar Kanuk, Consumer Behavior, New Jersey, Prentice Hall, 1997, p. 112

28 Robert R. McCrae - Paul T. Costa, “The Five-Factor Theory of Personality”, Handbook of Personality Theory and Research, Ed.: Oliver P. John, Richard W. Robins ve Lawrence A. Pervin, Amerika, The Guilford Press, 2008, p.159-181. p.162

29 Arnould et al., Consumers...ibid., p.390

30 Oliver John et al., "Paradigm Shift to the Integrative Big Five Trait Taxonomy: History, Measurement, and Conceptual Issues", Handbook of Personality Theory and Research, Ed.:Oliver P. John, Richard W. Robins ve Lawrence A. Pervin, New York, The Guilford Press, 2008, p.114-158. p.114-116

31 Lewis R. Goldberg, "An alternative description of personality: The big-five ve factor stru- 
of the factors within this typology, even though some researchers have different views, in general, more consensus has been reached on this model compared to other models related to personality traits. ${ }^{32}$

However, although consensus has been reached on the factors, a consensus on the expressions within these factors has not been reached. It can be seen that the number of expressions under these five factors display differences in different studies. ${ }^{33}$ For instance, these five factors involve 60 expressions in Costa \& McCrae's (1992) ${ }^{34}$ NEO-FFI personality inventory; 30 expressions in Costa \& McCrae's (1995) ${ }^{35}$ NEOPI-R inventory; 45 bipolar expressions in Hofstee et al.'s (1992) ${ }^{36}$ AB5C model; 20 expressions in Donellan et al.'s (2006) ${ }^{37}$ Mini-IPIP scale; 17 expressions in Korkmaz et al.'s $(2013)^{38} 5$ FKE inventory and have been measured in different numbers in many different studies.

It can be seen that the five-factor personality model, which has been developed as a result of the analysis of adjectives used by individuals to define themselves and others, ${ }^{39}$ has significant implications in the area of psychology. It shows that personality provides a significant typology which displays individual differences with five dimensions that are very independent of each other. In addition, since a generally accepted typology consists of standard vocabulary and terminology, it facilitates the collection of empirical findings and the formation of communication because of its

cture”, Journal of Personality and Social Psychology, Vol.59 No.6, 1990, p.1216-1229. p. 27; John et al., Paradigm...ibid., p.114-116

32 Paul T. Costa - Robert R. McCrae, "Domains and Facets: Hierarchical Personality Assessment Using the Revised NEO Personality Inventory", Journal of Personality Assessment, Vol.68 No.1, 1995 ,p. 21-50. ; Gerald Matthews et al., Personality Traits, Cambridge, Cambridge University Press, 2009, p. 24-25

33 Lewis R. Goldberg, “A broad-bandwidth, public-domain, personality inventory measuring the lower-level facets of several five-factor models", Personality Psychology in Europe, Vol. 7, 1999, p. 7-28. Ed.: I. Mervielde, I. J. Deary, F. De Fruyt, and F. Ostendorf, Tilburg, The Netherlands: Tilburg University Press. p. 9

34 Paul T. Costa - Robert R. McCrae, Revised NEO Personality Inventory (NEO- PI-R) and NEO Five-Factor (NEO-FFI) Inventory Professional Manual, Odessa, FL, PAR, 1992

35 Costa - McCrae, Domains...ibid.

36 Willem K. Hoftee et al., "Integration of big five and circumplex approaches to trait structure”, Journal of Personality and Social Psychology, Vol.63 No.1, 1992, p.146-163

37 M. Brent Donnellan et al., "The Mini-IPIP Scales: Tiny-Yet-Effective Measures of the Big Five Factors of Personality”, Psychological Assessment, Vol.18 No.2, 2006, p.192-203.

38 Mediha Korkmaz et al., "Ergen Örneklemde Beş Faktör Kişilik Envanteri’nin Cinsiyetlere Göre Ortalama ve Kovaryans Yapılarıyla Ölçme Eşdeğerliği”, Eğitim ve Bilim, Vol.38 No.170, 2013, p.121-134

39 Oliver P. John - Sanjay Srivastava, "The Big Five Trait Taxonomy: History, Measurement, and Theoretical Perspectives", Handbook of Personality: Theory and Research, Ed.: Lawrence A. Pervin and Oliver P. John, New York, Guilford Press, 1999, p.102-138 
common terminology. ${ }^{40}$ Personality has been classified in accordance with the generally accepted five-personality typology as: openness to experience, conscientiousness, extraversion, agreeableness and neuroticism. ${ }^{41}$

The dimensions in typology have been obtained through natural and linguistic expressions used by individuals to define themselves and others, rather than being a reflection of a specific theoretical point of view. This typology, which has been named "The Big Five" (big five trait taxonomy), has not taken the place of many studies carried out previously in relation to personality traits and changed them; it has unified different and various systems related to the definition of personality under one roof. ${ }^{42}$

Openness to experience: This factor is the least agreed on factor by the researchers and has been defined as intelligence by some researchers, as culture by others and as openness to experiences by yet others. ${ }^{43}$ People whose openness to experience dimension is high are defined as people who look for variety, novelty, and change, ${ }^{44}$ as intellectual, imaginative and independent-minded, ${ }^{45}$ as giving importance to inner feelings and emotions and as inquisitive. ${ }^{46}$

Conscientiousness: People with a high conscientiousness dimension are defined as dutiful, achievement orientated, ordered, forward-planning, not giving up easily when they encounter hardships, self-disciplined, paying attention to detail. ${ }^{47}$

Extraversion: People with a high extraversion dimension are defined as social, outgoing, assertive, dominant, gregarious, interested in other people and positive. ${ }^{48}$

40 Murray R. Barrick - Michael K., “"The Big Five Personality Dimensions and Job Performance: A Meta-Analysis', Personnel Psychology, Vol.44, No.1, 1991, p.1-26, p.5; John et al., Paradigm...ibid., p.114-116

41 Costa - McCrae, Domains...ibid., p.21-50; Goldberg, An Alternative...ibid., p.1217; Lewis R. Goldberg, "The Structure of Phenotypic Personality Traits", American Psychologist, Vol. 48 No.1, 1993, p. 26-34.; P. Oliver John - Sanjay Srivastava "The Big Five Trait Taxonomy: History, Measurement, and Theoretical Perspectives", Handbook of Personality: Theory and Research, Ed.: Lawrence A. Pervin and Oliver P. John, New York, Guilford Press, 1999, p.102-138.

42 John et al., Paradigm...ibid., p.116

43 Oya Somer et al., "Beş Faktör Kişilik Envanteri’nin Geliştirilmesi-I: Ölçek ve Alt Ölçeklerin Oluşturulması", Türk Psikoloji Dergisi, Vol.17 No.49, 2002, p. 21- 33, p.24

44 McCrae - Costa, The Five-Factor...ibid., p.164

45 John - Srivastava, The Big...ibid., p.105

46 Joyce E. Bono et al., "The Role of Personality in Task and Relationship Conflict”, Journal of Personality, Vol. 70 No.3, 2002, p.311-344, p.320; Costa - McCrea, Domains...ibid., p.38

47 Bono et al., The Role...ibid., p.319; Costa - McCrea, Domains...ibid., p.38; McCrea Costa, The Five-Factor...ibid., p.164

48 Veronica Benet Martinez - Oliver P. John, "Los Cinco Grandes Across Cultures and Ethnic Groups: Multitrait Multimethod Analyses of the Big Five in Spanish and English", Journal of Personality and Social Psychology, Vol.75 No.3, 1998, p.729-750, p.734; Bono et al., The Role...ibid., p.319, McCrea - Costa, The Five-Factor...ibid., p.164 
Agreeableness: People with a high agreeableness dimension are defined as caring about others, altruistic, trusting, cooperative, compliant, forgiving. ${ }^{49}$

Neuroticism (Emotional Stability): People with a high neuroticism dimension are defined as having negative characteristics, such as being anxious, self-conscious, vulnerable and experiencing anger, hostility and pessimistic attitudes. ${ }^{50}$

These different personality traits can have a substantial effect on the choices people make: their selection of products and brands; the reactions they have to activities which companies carry out with the purpose of promotion; when, where and how they consume goods or services. ${ }^{51}$ Because of the effect that personality traits have on activities carried out with the purpose of promotion, it can be said that individuals with different personality traits have different reactions to advertisements, which are one type of promotion activity. Therefore, it can be stated that individuals with different personality traits can display differences with regard to their belief in the claims presented in advertisements and also with regard to their suspicious approach towards advertisements.

Scepticism towards advertisements creates a general belief about them. Therefore, it must also be a factor when creating an attitude towards the market, for instance, in the approach to advertisement and marketing. Since consumers who feel scepticism towards advertisements have a tendency not to like them, they also have a tendency to dislike the marketing activities. Thus, the personality and life experiences, thoughts and attitudes of consumers about the market shape the general opinion they hold about advertisements. Besides consumer experiences, personality traits, such as age, education, cynicism and confidence, also have an effect on scepticism towards advertisements. ${ }^{52}$

When the literature relating to scepticism towards advertisements is analysed, it can be seen that there are certain studies which analyse the relationship between scepticism towards advertisements and factors such as the personality traits, demographic characteristics, age, education, etc. of the consumers. For instance, Obermiller and Spangenberg, in their study dated $2000^{53}$, have analysed how scepticism towards advertisements shows differences in intergenerational terms and to which source among the five different information sources (where "advertisements" as a source of information is also present) consumers show the most scepticism. As a result of the study, it has been determined that out of the five different information sources, consumers show the most scepticism towards "advertisements". Boush et al.

49 Benet Martinez - John, Los...ibid., p.734; Bono et al., The Role...ibid., p.318, McCrea Costa, The Five-Factor...ibid., p.164

50 Costa - McCrae, Domains...ibid., p.38; McCrea - Costa, The Five-Factor...ibid., p.164; Somer et al., Beş...ibid., p.24

51 Schiffman - Kanuk, Consumer...ibid., p.114

52 Obermiller - Spangenberg, Development...ibid., p.167-169

53 Carl Obermiller - Eric R. Spangenberg, "On the Origin and Distinctness of Skepticism toward Advertising", Marketing Letters, Vol.11 No.4, 2000, p.311- 322 
$(1994)^{54}$ have analysed the scepticism shown by teenagers towards advertisements in their study and have carried out a study in relation to how persuasive these teenagers find the tactics employed by advertisers. Obermiller and Spangenberg (1998) ${ }^{55}$ have analysed the relationship between consumers' personality traits and scepticism towards advertisements in their study. However, in this study only personality traits such as being sceptical and having confidence have been taken into consideration and very few personality traits have been included in the scope of the study.

\section{Aim and Method}

When the literature is analysed, it can be seen that the concept of scepticism towards advertisements is generally considered in relation to subjects such as the context of advertisement messages or the demographic characteristics of a population. However, scepticism can originate from the personality traits of individuals. In the literature, it can be seen that studies which deal with the relationship between scepticism towards advertisements and individuals' personality traits are limited and that studies which do deal with this relationship take into consideration only a few of the individuals' characteristics as personality traits. However, no studies have been carried out which deal with scepticism towards advertisements in a detailed manner and within the context of currently accepted personality theories. This brings to the fore the problem of whether scepticism towards advertisements originates from personality traits or not. For this reason, this study has been aimed at determining the relationship between the scepticism felt towards advertisements by consumers and their personality traits, within the scope of the five-factor personality theory. Accordingly, the following hypothesis has been developed to be tested in the study:

H1: Scepticism felt by consumers towards advertisements is related to the dimensions of (a) Conscientiousness (b) Agreeableness, (c) Extraversion, (d) Openness to Experience and (e) Emotional Stability.

\subsection{Participants}

The study has been carried out on 132 people, who have been selected through convenience sampling. In the study, the survey form has been prepared on an online survey site and attempts have been made to reach participants by sharing the survey link on various social media platforms.

$57 \%$ of the participants are female and $81 \%$ consists of people between the ages of 18 and $29.61 \%$ of the participants are university graduates and the income level of $63 \%$ is between $1.000 \mathrm{TL}$ and $5.000 \mathrm{TL}$ (Table 1).

54 Bousch et al., Adolescent...ibid.

55 Obermiller - Spangenberg, Development...ibid. 
Table 1: Demographic Data

\begin{tabular}{|l|l|c|c|}
\hline \multicolumn{2}{|l|}{ Demographic Variables } & Frequency & Percentage \\
\hline Sex & Male & 57 & 43 \\
\hline & Female & 75 & 57 \\
\hline Age & $18-24$ & 51 & 39 \\
\hline & $25-29$ & 55 & 42 \\
\hline & $30-39$ & 15 & 11 \\
\hline & 40 and over & 11 & 8 \\
\hline Education & High School & 38 & 29 \\
\hline & University & 81 & 61 \\
\hline & Post-Graduate & 13 & 10 \\
\hline Income Level & Less than 1.000 TL & 32 & 24 \\
\hline & 1.000 TL-2.999TL & 41 & 31 \\
\hline & 3.000 TL-4.999 TL & 42 & 32 \\
\hline & 5.000 TL and over & 17 & 13 \\
\hline
\end{tabular}

\subsection{Data Collection Tool}

In order to evaluate the level of scepticism displayed by participants towards advertisements, the SKEP scale, developed by Obermiller and Spanganberg (1998), ${ }^{56}$ has been used. The scale consists of a total of nine expressions arranged in the 5-point Likert scale (5: I totally agree; 1: I totally disagree) (example expressions: "Advertising's aim is to inform the consumer", "Advertising is a reliable source of information about the quality and performance of products", "In general, advertising presents a true picture of the product being advertised"). According to this, a high score achieved from the scale shows that the person approaches advertisements with scepticism and low scores show the exact opposite. The Cronbach's Alpha value calculated for the scale is 0,88 .

In the study, in order to measure the personality traits of the participants, the scale developed by Donnellan et al. (2006) ${ }^{57}$ has been used. The scale has been developed in accordance with the five-factor personality theory and measures the five basic personality traits (conscientiousness, agreeableness, extraversion, openness to experiences, emotional stability). There are a total of 20 expressions arranged in the 5-point Likert scale (5: I totally agree; 1 : I totally disagree), with four expressions for each of the personality traits. According to this: a high score achieved in the "Conscientiousness" dimension expresses that the person does not give up easily in the face of hardships, pays attention to detail, acts in a planned manner and is ordered and disciplined (example expression: "I like order"); a high score achieved in the "Agreeableness" dimension expresses that the person cares for others, is helpful and gets along easily with others (example expression: "I sympathize with others' feelings"); a high score achieved in the "Extraversion" dimension expresses that the person is social, outgoing, assertive, dominant and interested in other people (example expression: "I talk to a lot of different people at parties"); a high score achieved in the "Openness to

Obermiller - Spangenberg, Development...ibid. 
Experience" dimension expresses that the person constantly produces new ideas, has different areas of interest, has high creativity and is not one-track minded (example expression: "I have a vivid imagination"); a high score achieved in the "Emotional Stability" dimension expresses that the person is optimistic, does not easily get angry and has low anxiety levels (example expression: "I am relaxed most of the time"). In the scale, the "Neuroticism" (emotional stability) dimension has been dealt with positively as emotional stability. The Cronbach's Alpha values calculated for the dimensions in the scale range between 0,86 and 0,91 .

\subsection{Statistical Analysis}

In the study, with the purpose of determining personality traits in relation to consumers' levels of scepticism in approaching advertisements, correlation analysis has been carried out. In order to determine the personality traits which have an effect on consumers' levels of scepticism in approaching advertisements, multiple regression analysis has been used.

\subsection{Findings}

According to the result achieved from the scale used to measure consumers' scepticism towards advertisements in the study (Table 2), consumers who have participated in the study approach advertisements with scepticism $(\mathrm{O}=3,92)$. When the personality traits of consumers are analysed, consumers who have participated in the study have defined themselves as individuals caring for others, helpful and getting along well with others (Agreeableness $=4,14$ ); social, assertive, dominant and interested in other people (Extraversion=4,06); and constantly producing new ideas, having different areas of interest, having high creativity and not being one-track minded (Openness to Experience=4,04).

Table 2: Average and Standard Deviation Values Achieved from the Scales and Correlation Analysis Results

\begin{tabular}{|l|c|c|c|c|c|c|c|c|}
\hline & A & SD & (1) & (2) & (3) & (4) & (5) & (6) \\
\hline $\begin{array}{l}\text { (1) Scepticism Towards } \\
\text { Advertisements }\end{array}$ & 3,92 & 0,74 & 1 & & & & & \\
\hline (2) Conscientiousness & 3,67 & 0,73 & $-0,12$ & 1 & & & & \\
\hline (3) Agreeableness & 4,13 & 0,73 & 0,13 & $0,30^{*}$ & 1 & & & \\
\hline (4) Extraversion & 4,06 & 0,69 & $0,22^{*}$ & 0,11 & 0,20 & 1 & & \\
\hline (5) Openness to Experience & 4,04 & 0,72 & $0,22^{*}$ & 0,09 & $0,29^{*}$ & $0,27 *$ & 1 & \\
\hline (6) Emotional Stability & 3,10 & 0,83 & 0,09 & 0,13 & 0,01 & 0,01 & $-0,16$ & 1 \\
\hline
\end{tabular}

$* \mathrm{p}<0,05$

Correlation analysis has been carried out to analyse the relationship between the consumers' levels of scepticism in approaching advertisements and personality traits. Since both of the variables are in the interval scale, correlation analysis has 
been preferred. The analysis is carried out in order to determine whether there is a direct relationship between the two variables. If there is a relationship, then the result of the analysis shows that the direction of this relationship is positive or negative. According to the results of the analysis (Table 2), it can be seen that only the Extraversion and Openness to Experience dimensions among the five personality traits have a significant relationship with consumers' levels of scepticism towards advertisements (Hypothesis $\mathrm{c}$ and d Accepted). Both personality traits have a positive relationship with scepticism; however, the relationship is at a low level $(\mathrm{r}<0,40)$. According to this, as the characteristics of being social, assertive, dominant, interested in other people, constantly producing new ideas, having different interest areas, having high creativity and not being one-track minded increases in consumers, their levels of scepticism in approaching advertisements increases as well.

To be able to understand whether demographic characteristics have a role or not in the relationship between the levels of scepticism in consumers' approach to advertisements with personality, an analysis has been made of whether scepticism towards advertisements changes in accordance with the demographic characteristics of consumers. Since the sex variable has two categories, the difference between the categories has been analysed with the $t$ test (in the $t / F$ column in the table, the value for the Sex variable is the $t$ value) and since the other variables have more than two categories, the differences between the categories has been analysed with the one way ANOVA analysis (in the $\mathrm{t} / \mathrm{F}$ column in the table, all values for the variables with the exception of the Sex variable are the F value). According to the results of the analysis (Table 3), it can be seen that the levels of scepticism in consumers' approach to advertisements do not differ to any significant degree according to any demographic characteristic. In view of this, it is possible to claim that whether scepticism towards advertisements is related to personality traits or not can be determined independently of the participants' demographic characteristics, such as sex, age, education and income level.

Table 3: Differences of the Results Achieved from the Scepticism towards Advertisements Scale in Accordance with the Participants' Demographic Data

\begin{tabular}{|c|c|c|c|c|c|}
\hline \multicolumn{2}{|c|}{ Demographic Variables } & \multirow{2}{*}{$\begin{array}{l}\mathbf{A} \\
3,94 \\
\end{array}$} & \multirow{2}{*}{$\begin{array}{l}\text { SD } \\
0,77 \\
\end{array}$} & \multirow{3}{*}{$\frac{\mathbf{t} / \mathbf{F}}{0,38}$} & \multirow{3}{*}{$\frac{\mathbf{P}}{0,71}$} \\
\hline \multirow{2}{*}{ Sex } & Male & & & & \\
\hline & Female & 3,89 & 0,71 & & \\
\hline \multirow{4}{*}{ Age } & $18-24$ & 3,89 & 0,67 & \multirow{4}{*}{0,03} & \multirow{4}{*}{0,99} \\
\hline & $25-29$ & 3,93 & 0,63 & & \\
\hline & $30-39$ & 3,95 & 1,14 & & \\
\hline & 40 and over & 3,90 & 0,94 & & \\
\hline \multirow{3}{*}{ Education } & High School & 3,81 & 0,59 & \multirow{3}{*}{0,71} & \multirow{3}{*}{0,50} \\
\hline & University & 3,92 & 0,83 & & \\
\hline & Post-Graduate & 4,10 & 0,28 & & \\
\hline \multirow{4}{*}{ Income level } & Less than $1.000 \mathrm{TL}$ & 3,75 & 0,65 & \multirow{4}{*}{0,83} & \multirow{4}{*}{0,48} \\
\hline & $1.000 \mathrm{TL}-2.999 \mathrm{TL}$ & 3,96 & 0,82 & & \\
\hline & $3.000 \mathrm{TL}-4.999 \mathrm{TL}$ & 4,02 & 0,80 & & \\
\hline & $5.000 \mathrm{TL}$ and over & 3,88 & 0,51 & & \\
\hline
\end{tabular}


In order to determine the effect of consumers' personality traits on their approach to advertisements with scepticism, the multiple regression analysis has been carried out. Since the dependent and independent variables are in the interval scale, regression analysis has been preferred. Since the independent variables are more than one, the multiple regression analysis has been used. The multiple regression analysis is used to determine the effect of two or more independent variables which have an impact, or are considered to have an impact, on the dependent variable. If any of the independent variables have a significant impact on the dependent variable, then the analysis shows that this impact is positive or negative and its coefficient. In the result of the analysis (Table 4), a significant model has been achieved $(\mathrm{R} 2=0,13 \mathrm{~F}=3,71 \mathrm{p}=0,00<0,01)$. The model's power of explaining the impact of personality traits on the levels of consumers' scepticism in approaching advertisements is $13 \%$. According to this model, it can be seen that the Conscientiousness (Standard Beta $=-0,20 \mathrm{p}=0,02<0,05$ ), Extraversion (Standard Beta=0,17p=0,04<0,05) and Openness to Experience (Standard Beta $=0,18 p=0,04<0,05$ ) dimensions among the personality traits have a significant impact on the levels of consumers' scepticism in approaching advertisements. Among the traits in question, while the impact of Conscientiousness on the level of approaching advertisements with scepticism is negative, the impact of the other two dimensions is positive. In the correlation analysis, while the impact of Conscientiousness does not display a significant relationship with scepticism in approaching advertisements, its significant impact in the regression analysis shows that this personality traits gains importance when it is taken into consideration alongside the other personality traits. According to this, consumers having high mental curiosity, being social and having extrovert characteristics on the one hand, while not paying attention to detail and having the tendency to act without planning on the other, increases the level of scepticism in approaching advertisements.

Table 4: The Regression Analysis Results Related to the Impact of Personality Traits on the Levels of Scepticism in Consumers' Approach to Advertisements

\begin{tabular}{|l|l|l|l|l|l|}
\hline & DV & $\begin{array}{l}\text { Standard } \\
\text { Error }\end{array}$ & $\begin{array}{l}\text { Standard } \\
\text { Beta }\end{array}$ & $\mathbf{t}$ & $\mathbf{P}$ \\
\hline (Fixed) & 2,36 & 0,59 & & 3,99 & $0,00^{* *}$ \\
\hline Conscientiousness & $-0,20$ & 0,09 & $-0,20$ & $-2,31$ & $0,02^{*}$ \\
\hline Agreeableness & 0,10 & 0,09 & 0,10 & 1,11 & 0,26 \\
\hline Extraversion & 0,18 & 0,09 & 0,17 & 1,98 & $0,04^{*}$ \\
\hline Openness to Experience & 0,19 & 0,09 & 0,18 & 2,02 & $0,04^{*}$ \\
\hline Emotional Stability & 0,12 & 0,07 & 0,14 & 1,64 & 0,10 \\
\hline
\end{tabular}

Dependent Variable: Scepticism towards Advertisements

$\mathrm{R} 2=0,13 \mathrm{~F}=3,71 \mathrm{p}=0,00<0,01$

$* \mathrm{p}<0,05 * * \mathrm{p}<0,01$ 


\section{Conclusion}

As the awareness of consumers increases day by day, so a more critical point of view towards the messages transmitted through advertisements is created. It can be seen that consumers who approach advertisements with scepticism sometimes do not believe the claims and justifications presented in advertisements. Consumers, in particular, who have information about the different persuasion tactics used are observed to change their reactions towards these messages. The acquisition of information related to persuasion that individuals obtain throughout their lives is made possible by their communication with other individuals, families, people in their work environments, etc. The development of consumers into individuals who very actively analyse the messages transmitted to them through advertisements, rather than receiving them passively, and who are beginning to approach advertisements with increasing scepticism has brought differences in the strategies used for advertisements as well.

As a result of certain studies, it has been determined that the scepticism in approaching advertisements differs in accordance with many factors, such as consumers' personality traits and demographic characteristics (like age, education). However, when the studies conducted in this area are analysed, studies which deal with the relationship between the scepticism of consumers in approaching advertisements and personality traits, do not take into consideration different personality traits in any depth. Therefore, in this study, the approach of consumers to advertisements with scepticism has been analysed within the framework of the five-factor personality theory and the relationship between scepticism in approaching advertisements and personality traits has been attempted to be determined.

According to the results of the study, it has been determined that the Openness to Experience, Extraversion and Conscientiousness dimensions among the five personality characteristics have an impact on the levels of scepticism in consumers' approach to advertisements. According to this, people who are intellectuals, independent minded, have a tendency to learn new things, embrace change or attempt these and have social characteristics such as extroversion and confidence approach advertisements with more scepticism. Within this framework, it can be seen that consumers who have mental curiosity and are open to experience, (seeking novelty, variety and change, for instance) have a tendency not to be content with the information presented to them through advertisements and consequently to question them; meanwhile, individuals who are sociable and extrovert ask their friends whether the information transmitted in advertisements is true or not and are able to verify it, since their contacts with family, friends and colleagues are extensive. In the study, the "Conscientiousness" dimension not having a significant relationship with scepticism towards advertisements as a result of the correlation analysis, but on the other hand, having a significant impact on scepticism towards advertisements as a result of the regression analysis, shows that this personality trait increases in importance when it is taken into consideration in combination with the other personality traits. In other words, Conscientiousness comes to the fore alongside the Openness to Experience and Extraversion characteristics. When all these types of approach are taken into consideration, it can be seen that individuals who have weak self discipline, do not pay attention to detail 
or do not act in a planned manner approach advertisements with more scepticism if their mental curiosity and sociability is high.

In accordance with the results of the study, companies or advertising agencies which produce advertisements for products and services which target consumers with high mental curiosity and sociability are advised to create messages taking into consideration the kinds of tactics that are effective in increasing the believability of advertisements. When they are designing messages which target people who are open to new experience and have a tendency to learn and try new things, advertisers should determine their strategies carefully, considering, in particular, how they can attract their interest more effectively. In this way, it will be possible for advertisements to serve their purpose so that the target groups act upon the messages they receive. 


\section{References}

ARNOUlD, Eric. J, Price, Linda, Zinkhan, George M., Consumers, America, Mc Graw Hill, 2004.

BARRICK, Murray R., Mount, Michael K., “'The Big Five Personality Dimensions and Job Performance: A Meta-Analysis', Personnel Psychology, Vol.44, No.1 , 1991, p.1-26.

BENET MARTINEZ, Veronica, John, Oliver P. "Los Cinco Grandes Across Cultures and Ethnic Groups: Multitrait Multimethod Analyses of the Big Five in Spanish and English", Journal of Personality and Social Psychology, Vol.75 No.3, 1998, p.729-750.

BELCH, George E., Belch, Michael A., Advertising and Promotion: An Integrated Marketing Communications Perspective, America, Mc Graw Hill, 2003.

BONO, Joyce E., Boles, Terry L., Judge, Timothy A., Lauver, Kirsty J., “The Role of Personality in Task and Relationship Conflict", Journal of Personality, Vol. 70 No.3, 2002, p.311-344.

BOUSCH, David M., Friestad, Marian, Rose, Gregory M. “Adolescent Skepticism toward TV Advertising and Knowledge of Advertiser Tactics”, Journal of Consumer Research, Vol.21, No.1, 1994, p.165-175.

CAMPBELL, Margaret C., "When Attention-Getting Advertising Tactics Elicit Consumer Inferences of Manipulative Intent: The Importance of Balancing Benefits and Investments", Journal of Consumer Psychology, Vol. 4 No.3, 1995, p.225-254.

CEVIZCİ, Ahmet, Felsefe Tarihi, İstanbul, Say Yayınları, 2010.

CEVIZCİ, Ahmet, Felsefe Sözlüğü, İstanbul, Paradigma Yayıncılık, 2005.

COSTA, Paul T., McCrae, Robert R., "Domains and Facets: Hierarchical Personality Assessment Using the Revised NEO Personality Inventory", Journal of Personality Assessment, Vol.68 No.1, 1995, p. 21-50.

COSTA, Paul. T., McCrae, Robert R. Revised NEO Personality Inventory (NEOPI-R) and NEO Five-Factor (NEO-FFI) Inventory Professional Manual, Odessa, FL, PAR, 1992.

DONNELLAN, M. Brent, Oswald, Frederick L., Baird, Brendan M., Lucas, Richard E., "The Mini-IPIP Scales: Tiny-Yet-Effective Measures of the Big Five Factors of Personality", Psychological Assessment, Vol.18 No.2, 2006, p.192203.

ELPEZE ERGEÇ, Nüket, “Ad Tactics And Skepticism”, 4th International Symposium Communication in the Millennium, Eskişehir, 14-16 June 2006, p.154164.

FRIESTAD, Marian, Wright, Peter, “The Persuasion Knowledge Model: How People Cope with Persuasion Attempts", Journal of Consumer Research, Vol.21 No.1, 1994,p.1-31. 
GOLDBERG, Lewis R., "An alternative description of personality: The big-five ve factor structure", Journal of Personality and Social Psychology, Vol.59 No.6, 1990, p.1216-1229.

GOLDBERG, Lewis R., “The Structure of Phenotypic Personality Traits”, American Psychologist, Vol. 48 No.1, 1993, p. 26-34.

GOLDBERG, Lewis R., “A broad-bandwidth, public-domain, personality inventory measuring the lower-level facets of several five-factor models", Personality Psychology in Europe, Vol. 7, 1999, p. 7-28. Ed.: I. Mervielde, I. J. Deary, F. De Fruyt, and F. Ostendorf, Tilburg, The Netherlands: Tilburg University Press.

HOFSTEE, Willem K., Raad, Boele de, Goldberg, Lewis R., "Integration of big five and circumplex approaches to trait structure", Journal of Personality and Social Psychology, Vol.63 No.1, 1992, p.146-163.

JOHN, Oliver. P., Naumann, Laura P., Soto, Christopher J. Soto, "Paradigm Shift to the Integrative Big Five Trait Taxonomy: History, Measurement, and Conceptual Issues", Handbook of Personality Theory and Research, Ed.:Oliver P. John, Richard W. Robins ve Lawrence A. Pervin, New York, The Guilford Press, 2008, p.114-158.

JOHN, P. Oliver, Srivastava, Sanjay, “The Big Five Trait Taxonomy: History, Measurement, and Theoretical Perspectives", Handbook of Personality: Theory and Research, Ed.: Lawrence A. Pervin and Oliver P. John, New York, Guilford Press, 1999, p.102-138.

KIRMANI, Amna, Zhu, Rui Juliet. "Vigilant Against Manipulation: The Effect of Regulatory Focus on the Use of Persuasion Knowledge”, Journal of Marketing Research, Vol. 44 No.4, 2007, p.688-701.

KORKMAZ, Mediha, Somer, Oya, Güngör, Duygu, "Ergen Örneklemde Beş Faktör Kişilik Envanteri'nin Cinsiyetlere Göre Ortalama ve Kovaryans Yapılarıyla Ölçme Eşdeğerliği’”, Eğitim ve Bilim, Vol.38 No.170, 2013, p.121-134.

KOTLER, Philip, Armstrong, Gary, Principles of Marketing, New Jersey, Pearson Prentice Hall, 2008.

MANGLEBURG, Tamara F., Bristol, Terry, "Socialization and Adolescents' Scepticism toward Advertising”, Journal of Advertising, Vol.27 No.3, 1998, p.1121.

MATTHEWS, Gerald, Deary, Ian J., Whiteman, Martha C., Personality Traits, Cambridge, Cambridge University Press, 2009.

McCRAE, Robert R., Costa, Paul T., "The Five-Factor Theory of Personality”, Handbook of Personality Theory and Research, Ed.: Oliver P. John, Richard W. Robins ve Lawrence A. Pervin, Amerika, The Guilford Press, 2008, p.159-181.

MOREL, Kaj P.N., Pruyn, Ad Th.H. "Consumer Scepticism Toward New Products", E-European Advances in Consumer Research, Ed.: Darach Turley and Stephen Brown, Provo, UT, Association for Consumer Research, 2003, p.351-358. 
OBERMILLER, Carl, Spangenberg, Eric R. "Development of a Scale to Measure Consumer Skepticism Toward Advertising”, Journal of Consumer Psychology, Vol.7, No.2, 1998, p. 159-186.

OBERMILLER, Carl, Spangenberg, Eric R., "On the Origin and Distinctness of Skepticism toward Advertising", Marketing Letters, Vol.11 No.4, 2000, p.311- 322 .

OBERMILLER, Carl, Spangenberg, Eric, MacLachlan, Douglas L. "Ad Skepticism: The Consequences of Disbelief", Journal of Advertising, Vol.34 No.3, 2005, p.7-17.

ODABAŞı, Yavuz, Barış, Gülfidan, Tüketici Davranışı, İstanbul, Kapital Medya Hizmetleri A.Ş, 2007.

O'SHAUGHNESSY, John, O'Shaughnessy, Nicholas Jackson, Persuasion in Advertising, London, Routledge, 2003.

PARSONS, Elizabeth, Maclaran, Pauline, Contemporary Issues in Marketing and Consumer Behaviour, Oxford, Butterworth - Heinemann, 2009.

PHILLIPS, Michael, Rasberry, Salli, Marketing Without Advertising, USA, Nolo, 2001.

RITCHIE, Robin J. B, "The Mutable Meaning of Ads: Advertising thorough the Eyes of the Skeptical Consumer", Faculty of Commerce. University of British Columbia. Working Paper-Version, 2001.

SCHIFFMAN, Leoon G., Kanuk, Leslie Lazar, Consumer Behavior, New Jersey, Prentice Hall, 1997.

SKIRBEKK, Gunnar, Gilje, Nils, Antik Yunan'dan Modern Döneme Felsefe Tarihi, Translated by: Emrah Akbaş and Şule Mutlu, İstanbul, Kesit Yayınları, 2006 (Original Book Published in 2001).

SOMER, Oya, Korkmaz, Media, Tatar, Arkun, "Beş Faktör Kişilik Envanteri'nin Geliştirilmesi-I: Ölçek ve Alt Ölçeklerin Oluşturulması”, Türk Psikoloji Dergisi, Vol.17 No.49, 2002, p. 21- 33.

SOSA, Ernest, Barry, Stroud. "Philosophical Scepticism and Epistemic Circularity", Supplementary Volumes, Vol.68, 1994, p. 263-307.

VOLLMER, Christopher, Precourt, Geoffrey, Always On: Advertising, Marketing, and Media in an Era of Consumer Control, Amerika, Mc Graw Hill, 2008.

WELLS, William, Burnett, John, Moriarty, Sandra, Advertising Principles and Practice. New Jersey, Pearson Prentice Hall, 2006. 